\title{
AN INVENTORY MODEL OF THREE-LAYER SUPPLY CHAIN OF WOOD AND FURNITURE INDUSTRY IN THE CARIBBEAN REGION OF COLOMBIA
}

Salas-Navarro, Katherinne; Chedid Acevedo, Jaime; Caruso Mercado, Nohora; Sana Sankar, Shib

\begin{abstract}
This article deals with a mathematical model for multi-item inventory system under a collaborative scheme in a three-level supply chain consisting of multiple raw material suppliers, multiple manufacturers and multiple retailers in which different cycle lengths and stochastic demand and production rates are considered for the purpose of evaluating the optimal solution. The model is also validated in the supply chain of wood and furniture industry in the Caribbean region of Colombia. In the process, suppliers of raw wood (sawmills), manufacturers of home furnishings and major retailers are participated. Results include a comparison between three-level and two-level supply chains using the collaborative scheme as well as for the noncollaborative scheme among the participating members of the chain.
\end{abstract}

\section{Keywords}

Collaboration, Inventory, Supply chain, Wood and furniture industry 